\title{
Epidemiology of Visceral Leishmaniasis in a Reemerging Focus of Intense Transmission in Minas Gerais State, Brazil
}

\author{
Ricardo Andrade Barata, ${ }^{1}$ Jennifer Cunha Peixoto, ${ }^{1}$ Aline Tanure, ${ }^{1}$ \\ Marcela Esteves Gomes, ${ }^{1}$ Estefânia Conceição Apolinário, ${ }^{1}$ Emerson Cotta Bodevan, ${ }^{1}$ \\ Holbiano Saraiva de Araújo, ${ }^{2}$ Edelberto Santos Dias, ${ }^{3}$ and Aimara da Costa Pinheiro ${ }^{4}$ \\ ${ }^{1}$ Universidade Federal dos Vales dos Jequitinhonha e Mucuri, Diamantina, MG, Brazil \\ ${ }^{2}$ HSA Gestão e Projeto Ambiental Ltda, Belo Horizonte, MG, Brazil \\ ${ }^{3}$ Centro de Pesquisas René Rachou/FIOCRUZ, Belo Horizonte, MG, Brazil \\ ${ }^{4}$ Secretaria Municipal de Saúde, Governador Valadares, MG, Brazil
}

Correspondence should be addressed to Ricardo Andrade Barata; ricbarata@hotmail.com

Received 15 April 2013; Revised 17 June 2013; Accepted 15 July 2013

Academic Editor: Milton Ozório Moraes

Copyright (C) 2013 Ricardo Andrade Barata et al. This is an open access article distributed under the Creative Commons Attribution License, which permits unrestricted use, distribution, and reproduction in any medium, provided the original work is properly cited.

\begin{abstract}
This study was developed in the urban area of Governador Valadares, a reemerging focus of intense transmission of visceral leishmaniasis (VL) in Brazil, presenting 86 human cases of VL from 2008 to 2011. The disease prevailed in males (73.2\%) with most patients between 0 and 9 years (44.1\%) and a lethality rate of $16.2 \%$. A canine survey was carried out on 16,529 domestic dogs in 35 districts in the area and it showed that $30.2 \%$ of them (4,992 dogs) were positive for VL by serum assays. Prevalence ratios for canine VL varied between $13.6 \%$ and $53.4 \%$. The clinical exam of 343 seropositive dogs showed that $49.9 \%$ of them were considered symptomatic, with larger prevalence of canine VL being in short-furred animals (90\%). The entomological survey was performed in eight districts, where 2,539 phlebotomines were captured, preferentially in the peridomicile (84.5\%). Lutzomyia longipalpis was the predominant species (90\%) suggesting its participation in the VL transmission in the area. The correlation between canine prevalence and L. longipalpis density was evaluated.
\end{abstract}

\section{Introduction}

In Brazil, visceral leishmaniasis (VL) or kala-azar is one of the biggest concerns of public health due to its high morbid-mortality in nontreated cases [1]. The etiological agent Leishmania infantum chagasi is transmitted mainly through the bite of Lutzomyia longipalpis (Diptera, Psychodidae, Phlebotominae), which is infected when ingesting intracellular parasites from the peripheral blood of a dog (Canis familiaris), considered not only the main domestic reservoir but also an essential link for the maintenance of the VL epidemiological chain in urban areas [2-4].

In the last decades, the environmental modifications caused by man, the deforestation, the disordered city growth, the concomitant presence of $L$. longipalpis, and domestic animals, not to mention the precarious habitation conditions of the population, all contributed to the urbanization and geographical expansion of VL in Brazil and the emergence of new focuses or reactivation of old ones [5].

In Governador Valadares, located in Rio Doce Valey, MG, cases of VL were registered in the 60s [6]. When the visceral leishmaniasis control program was adopted, the municipality was considered as belonging to a "controlled endemic" area. However, in the beginning of the 90s, the program was interrupted and epidemiological surveillance has not been carried out regularly in the region since then, without notification of human cases of VL up to 2007.

Since 2008, human cases of VL began to be registered in the municipality of Governador Valadares. Given this situation, the present study undertakes an epidemiological investigation taking into account human and canine cases and also the phlebotomine fauna, in a reemergent focus of intense VL transmission in Brazil. 


\section{Materials and Methods}

2.1. Study Area. The municipality of Governador Valadares $\left(18^{\circ} 51^{\prime} 12^{\prime \prime} \mathrm{S}-41^{\circ} 56^{\prime} 42^{\prime \prime} \mathrm{W}\right)$ is located in the eastern region of Minas Gerais state, covering part of the Rio Doce basin, in the southeastern area of Brazil. The city has 263,689 inhabitants distributed in 150 districts [7]. The region is subjected to a hot and humid climate in which temperatures vary little throughout the year (annual temperature average of $25.6^{\circ} \mathrm{C}$ ). Its topography is characterized by a hilly relief. The vegetation is between the ecosystems of seasonal semidecidual forest and savannah, but due to logging in the past, some native species were replaced by pastures, with some representatives in areas of environmental protection in the municipal surrounding areas.

2.2. Human Cases of VL. Data concerning the number of human cases of VL in the urban area of Governador Valadares from 2008 to 2011 was obtained from the Epidemiology Management/DVS/SMS, that considered the municipality as an area of intense VL transmission (average of cases in the last 5 years $\geq 4.4$ cases) in the state of Minas Gerais [5].

2.3. Canine VL Survey. The canine VL (CVL) survey was carried out from 2008 to 2011 in all dogs domiciled in neighborhoods in the urban area with records of human cases in Governador Valadares. Blood samples were obtained annually in all the districts through the cervical or jugular vein puncture for serum production. A first screening for the presence of anti-Leishmania immunoglobulin in canine serum was performed by ELISA (Bio-Manguinhos/Fiocruz, RJ, Brazil) [8]. The diagnosis confirmation was accomplished through the indirect immunofluorescence assay (IFAT) [9], in agreement with the procedure adopted by the Brazilian Ministry of Health [5]. Among the positive animals for IFAT, a random sample of 343 dogs was analyzed according to the clinical characteristics of the animal. They were organized into asymptomatic or symptomatic groups, according to the absence or presence of at least one sign of VL infection (i.e., cutaneous lesions, onychogryphosis, keratoconjunctivitis, weight loss, emaciation, and rigidity of subsequent limbs) [10]. In addition, they were classified in short-furred (i.e., Basset, Beagle, Boxer, Brazilian Fila, Doberman, Pinscher, Pit-bull, Rottweiler, Shar pei, Weimaraner, and Mongrel) and long-furred dogs (i.e., Cocker, Siberian husky, Labrador, Lhasa-apso, German Shepherd, and Poodle).

2.4. Entomological Captures. Phlebotomine captures were performed in 8 neighborhoods in the municipality of Governador Valadares (Altinópolis, Mãe de Deus, Nossa Senhora das Graças, Santa Helena, Ilha de Araújos, Santos Dumont, São Raimundo, and Turmalina). The neighborhoods were chosen taking into account the prevalence rates canine (high and low). Thirty-two HP light traps [11] were distributed in the intra- and peridomicile, exposed in two residences of each neighborhood. The residences were chosen according to favorable ecological conditions for their development, such as the presence of trees, domestic animals, and organic matter.
TABLE 1: Distribution of human cases of VL according to age, sex, and lethality in Governador Valadares from 2008 to 2011.

\begin{tabular}{lccccc}
\hline $\begin{array}{l}\text { Age group } \\
\text { (years) }\end{array}$ & \multicolumn{2}{c}{ VL human cases } & Total & $\%$ & Lethality $(N)$ \\
\hline $0-9$ & Female & Male & & & \\
$10-19$ & 15 & 23 & 38 & 44.1 & 5 \\
$20-29$ & 3 & 4 & 7 & 8.2 & 1 \\
$30-39$ & 1 & 3 & 4 & 4.7 & 1 \\
$40-49$ & 1 & 7 & 8 & 9.3 & 1 \\
$50-59$ & 1 & 16 & 17 & 19.8 & 2 \\
$60-69$ & 0 & 6 & 6 & 6.9 & 1 \\
$>70$ & 2 & 3 & 5 & 5.8 & 2 \\
\hline Total & 0 & 1 & 1 & 1.2 & 1 \\
\hline
\end{tabular}

Sand flies were captured with traps assembled at 4:00 pm and removed the following day at 8:00 am, for 3 consecutive nights each month, between May 2011 and January 2012. The specimens captured were conditioned into hemolysis tubes containing alcohol (70\%) and in accordance with Young and Duncan [12].

2.5. Statistical Analysis. The Shapiro-Wilk test was used to evaluate the normality of data distribution (Software: $\mathrm{R} \mathrm{v}$. 2.14.1). The Spearman correlation between the prevalence of canine infection and the density of L. longipalpis was calculated and its statistical significance assessed ( $P$ value $\leq 0.05)$.

2.6. Ethical Aspects. This study was conducted in accordance with the ethical principles of animal experimentation adopted by the Brazilian College of Animal Experimentation (COBEA) and it was approved by the Ethical Committees on the Use of Animals of Universidade Federal dos Vales do Jequitinhonha e Mucuri (CEUA/UFVJM 010/10, Diamantina, Brazil).

\section{Results}

The municipality of Governador Valadares presented 86 autochthonous cases of visceral leishmaniasis from 2008 to 2011, with 14 cases in 2008, 27 in 2009, 24 in 2010, and 21 in 2011 (data not showed). The disease prevailed in males (73.2\%), in children aged 0-9 years (44.1\%) with a lethality rate of $16.2 \%$ (Table 1 ).

The canine survey carried out in 35 districts of Governador Valadares from 2008 to 2011 resulted in 4,992 (30.2\%) VL-seropositive dogs among 16,529 tested (Table 2). Canine VL was widespread throughout the urban area, with prevalence rates varying from $13.6 \%$ (São Paulo district) to $53.4 \%$ (Carapina district) (Table 2). Among the 343 seropositive dog samples, $49.9 \%$ were considered symptomatic, with a larger prevalence of CVL in short-furred dogs (90\%) (Figure 1(a)). The most frequent clinical signs in symptomatic animals were located ulcers and onycohgryphosis, as evidenced in Figure 1(b). 
TABLE 2: Median prevalence of canine visceral leishmaniasis infection and number of human cases, by district, in Governador Valadares from 2008 to 2011.

\begin{tabular}{|c|c|c|c|c|}
\hline Districts & $\begin{array}{c}\text { Number of } \\
\text { dogs } \\
\text { examined }\end{array}$ & $\begin{array}{c}\text { IFAT-positive } \\
\text { dogs }\end{array}$ & $\begin{array}{c}\text { Prevalence } \\
\text { (\%) }\end{array}$ & $\begin{array}{l}\text { VL human } \\
\text { cases }\end{array}$ \\
\hline Altinópolis & 2,237 & 756 & 33.8 & 10 \\
\hline Atalaia & 47 & 18 & 38.3 & 1 \\
\hline Carapina & 189 & 101 & 53.4 & 2 \\
\hline Centro & 605 & 121 & 20.0 & 6 \\
\hline Esperança & 274 & 104 & 37.9 & 2 \\
\hline Esplanada & 166 & 85 & 51.2 & 1 \\
\hline Fraternidade & 262 & 63 & 24.0 & 1 \\
\hline Grã-Duquesa & 891 & 332 & 37.2 & 2 \\
\hline $\begin{array}{l}\text { Ilha dos } \\
\text { Araújos }\end{array}$ & 690 & 127 & 18.4 & 2 \\
\hline $\mathrm{JK}$ & 259 & 58 & 22.4 & 1 \\
\hline $\begin{array}{l}\text { Jardim do } \\
\text { Trevo }\end{array}$ & 683 & 185 & 27.1 & 3 \\
\hline Lourdes & 824 & 327 & 39.7 & 6 \\
\hline Maria Eugênia & 205 & 69 & 33.6 & 1 \\
\hline Mãe de Deus & 401 & 132 & 32.9 & 3 \\
\hline $\begin{array}{l}\text { Monte } \\
\text { Carmelo }\end{array}$ & $\mathrm{NU}$ & $\mathrm{NU}$ & - & 1 \\
\hline $\begin{array}{l}\text { N. Sra. das } \\
\text { Graças }\end{array}$ & 725 & 275 & 37.9 & 4 \\
\hline Palmeiras & 764 & 238 & 31.1 & 7 \\
\hline Planalto & 354 & 124 & 35.0 & 2 \\
\hline Santa Efigênia & 195 & 54 & 27.7 & 1 \\
\hline Santa Helena & 1,536 & 581 & 37.8 & 7 \\
\hline $\begin{array}{l}\text { Santa } \\
\text { Terezinha }\end{array}$ & 342 & 90 & 26.3 & 1 \\
\hline Santo Antônio & 519 & 148 & 28.5 & 3 \\
\hline $\begin{array}{l}\text { Santos } \\
\text { Dumont }\end{array}$ & 256 & 35 & 13.7 & 1 \\
\hline São Cristóvão & 268 & 64 & 23.9 & 2 \\
\hline São José & 165 & 24 & 14.5 & 1 \\
\hline São Paulo & 785 & 107 & 13.6 & 1 \\
\hline São Raimundo & 25 & 8 & 32.0 & 1 \\
\hline Turmalina & 946 & 194 & 20.5 & 3 \\
\hline Vila Bretas & 528 & 116 & 21.9 & 4 \\
\hline Vila Império & 226 & 46 & 20.3 & 1 \\
\hline Vila Isa & 230 & 68 & 29.5 & 1 \\
\hline Vila Mariana & 460 & 218 & 47.4 & 1 \\
\hline $\begin{array}{l}\text { Vila dos } \\
\text { Montes }\end{array}$ & 19 & 6 & 31.6 & 1 \\
\hline Vila Ozanã & 161 & 48 & 29.8 & 1 \\
\hline Vila Rica & 292 & 70 & 24.0 & 1 \\
\hline Total & 16,529 & 4,992 & 30.2 & 86 \\
\hline
\end{tabular}

NU: not undertaken.

The phlebotomine fauna in Governador Valadares urban area consisted of 4 species: Lutzomyia cortelezzii (Brèthes,
TABLE 3: Phlebotomine sandflies captured with HP trap in Governador Valadares by species, sex, and environment (from May 2011 to January 2012).

\begin{tabular}{lcccccc}
\hline \multirow{2}{*}{ Species } & \multicolumn{7}{c}{ Environment } & & \\
& $\$$ & Inside & \multicolumn{2}{c}{ Outside } & Total & $\%$ \\
\hline Lutzomyia cortelezzii & 26 & 13 & 79 & 63 & 181 & 7.1 \\
L. intermedia & 3 & 2 & 3 & 10 & 18 & 0.7 \\
L. longipalpis & 80 & 250 & 221 & 1,733 & 2,284 & 90.0 \\
L. whitmani & 1 & 2 & 0 & 1 & 4 & 0.1 \\
Lutzomyia spp. & 10 & 6 & 11 & 25 & 52 & 2.1 \\
\hline Subtotal & 120 & 273 & 314 & 1,832 & 2,539 & 100 \\
\hline
\end{tabular}

1923), Lutzomyia intermedia (Lutz and Neiva, 1912), Lutzomyia longipalpis (Lutz and Neiva, 1912), and Lutzomyia whitmani (Antunes and Coutinho, 1939), totaling 2,539 specimens, of which 2,105 were males (83\%) and 434 females (17\%). The peridomicile presented the largest percentage of the captured specimens (84.5\%). The predominant species was L. longipalpis (90\%) (Table 3). The phlebotomine distribution according to the neighborhoods and months of collection can be visualized in Table 4 .

The correlation between the density of the L. longipalpis captured and canine prevalence is represented in Figure 2. There was no statistically significant association between the variables number of sandflies and prevalence of canine infection $(P=0.057)$.

\section{Discussion}

In Brazil, VL is considered a neglected disease that prevails in places where underprivileged social conditions predominate. It contributes to the maintenance of the inequality picture that we have nowadays, as it represents a strong barrier to the social and economical development of the country [5]. In the last decades, the urbanization phenomenon has been pointed out as the responsible for the appearance of new focuses and reemergence of old ones in urban areas of small and mediumsized cities [13-15].

Governador Valadares, located in the Southeastern area of Brazil, is an example of a reemerging focus of VL as a result of urbanization. The VL cases notified occurred where housing conditions, basic sanitation, and garbage collection were poor. The residents have low socioeconomic status, living together with domestic animals and accumulated organic matter (data not shown). The same conditions were evidenced in other places where VL transmission is endemic $[16,17]$.

Analyzing the human cases according to the age group it was noticed that VL was more frequent in children under 10 years old (44.1\%) (Table 1). The same findings were reported by several authors [18-20]. The lethality rate was $16.2 \%$. Nascimento et al. [14] and Queiroz et al. [21] verified a lethality rate of $11.5 \%$ and $10.2 \%$, respectively. The greatest prevalence of VL in children (Table 1) can explain the high lethality rate found, as they are yet incompletely developed immune system. 
Table 4: Phlebotomine sandflies captured with HP trap in Governador Valadares by district and sex (from May 2011 to January 2012).

\begin{tabular}{|c|c|c|c|c|c|c|c|c|c|c|c|c|c|c|c|c|c|c|c|}
\hline \multirow{3}{*}{ Year } & \multirow{3}{*}{ Months } & \multicolumn{16}{|c|}{ Districts } & \multirow{3}{*}{$N$} & \multirow{3}{*}{$\%$} \\
\hline & & \multicolumn{2}{|c|}{ Altinópolis } & \multicolumn{2}{|c|}{$\begin{array}{l}\text { Mãe de } \\
\text { Deus }\end{array}$} & \multicolumn{2}{|c|}{$\begin{array}{l}\text { N. Sra. } \\
\text { Graças }\end{array}$} & \multicolumn{2}{|c|}{$\begin{array}{l}\text { Santa } \\
\text { Helena }\end{array}$} & \multicolumn{2}{|c|}{$\begin{array}{l}\text { Ilha dos } \\
\text { Araújos }\end{array}$} & \multicolumn{2}{|c|}{$\begin{array}{l}\text { Santos } \\
\text { Dumont }\end{array}$} & \multicolumn{2}{|c|}{$\begin{array}{c}\text { São } \\
\text { Raimundo }\end{array}$} & \multicolumn{2}{|c|}{ Turmalina } & & \\
\hline & & ㅇ & 0 & 우 & 0 & 우 & 0 & 우 & 0 & ㅇ & 0 & 우 & 0 & 우 & 0 & 우 & 0 & & \\
\hline \multirow{4}{*}{2011} & May & 17 & 28 & 58 & 278 & 8 & 27 & 32 & 98 & 0 & 0 & 0 & 1 & 0 & 0 & 0 & 1 & 548 & 21.6 \\
\hline & Jul & 8 & 34 & 20 & 153 & 7 & 49 & 19 & 72 & 0 & 0 & 0 & 0 & 0 & 2 & 0 & 0 & 364 & 14.4 \\
\hline & Sep & 3 & 5 & 4 & 8 & 5 & 10 & 7 & 29 & 0 & 0 & 1 & 5 & 0 & 0 & 0 & 0 & 77 & 3.0 \\
\hline & Nov & 21 & 33 & 15 & 7 & 8 & 25 & 11 & 57 & 3 & 1 & 0 & 0 & 0 & 1 & 3 & 4 & 189 & 7.4 \\
\hline 2012 & Jan & 19 & 299 & 99 & 315 & 56 & 549 & 10 & 14 & 0 & 0 & 0 & 0 & 0 & 0 & 0 & 0 & 1,361 & 53.6 \\
\hline Total & & & 67 & & 7 & & 14 & & 9 & & 4 & & & & & & & 2,539 & 100 \\
\hline
\end{tabular}

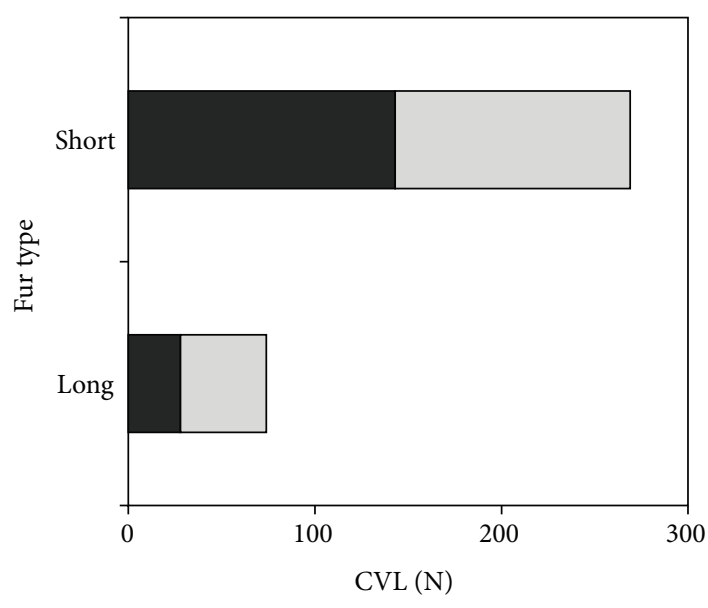

Symptomatic

$\square$ Asymptomatic

(a)

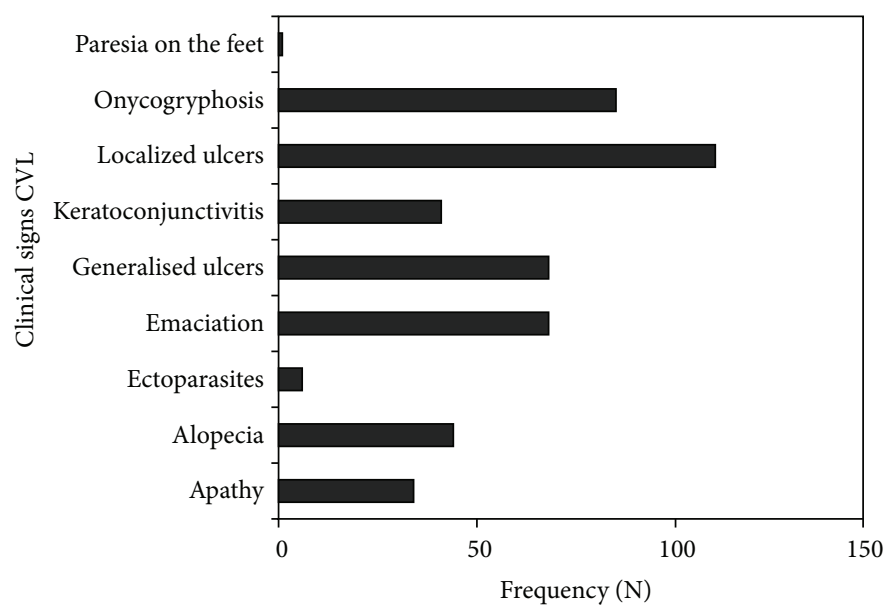

(b)

FIGURE 1: Frequencies of canine visceral leishmaniasis by fur type and clinical status (a) and the recorded clinical signs of CVL (b) in urban dogs of Governador Valadares, MG, Brazil.

The prevalence of canine-VL in Brazil has been demonstrated to be between 1.9 and 35\% in endemic areas [22-26]. In a previous study undertaken in Governador Valadares, Malaquias et al. [27] evidenced $13.7 \%$ of positivity in dogs in urban areas. In the present study, the average prevalence was $30.2 \%$, but in some neighborhood it reached $53.4 \%$. The high prevalence of canine infection has been given as one of the risk factors for VL occurrence $[28,29]$.

In this context, symptomatic or asymptomatic seropositive dogs play an important role in the maintenance of the infection [30]. Signs of VL were detected in 171 (49.9\%) of the 343 dogs sampled. The pattern of clinical signs observed for the disease most commonly included weight loss, apathy, and emaciation, similar to what was observed by Silva et al. [15]. The most worrying fact is the percentage of dogs with nonapparent infection (50.1\%), as they show a high degree of cutaneous parasitism, being capable of living together with the parasite for long periods $[31,32]$.

In addition, short-furred dogs represented the largest percentage of seropositive animals (90\%), suggesting that short fur determines larger chance by a greater propensity to contract the infection in the population investigated because it enables the phlebotomine access to the place of the bite $[33,34]$. These results are reinforced by França-Silva et al. [4] who observed a larger prevalence of CVL in short-furred dogs.

In Minas Gerais, several authors have showed the abundance of $L$. longipalpis in urban areas where VL is endemic $[16,35,36]$. The same pattern has been observed in other Brazilian areas $[37,38]$ where the species clearly participates in the transmission of $L$. infantum chagasi. However, in previous research in the same area as the present study, although the authors found L. longipalpis, it was not the most abundant species. This fact may be because the area sampled was a transitional one between wild and urban environments. Thus the predominance of this sand fly in an urban area with high frequencies in residences and surroundings suggests its participation in the transmission of L. infantum chagasi among dogs and humans in the city of Governador Valadares [39].

The presence of a great number of seropositive dogs and the high density of L. longipalpis have been affirmed to be the main risk factors for the occurrence of VL in urban areas $[40,41]$. In the present study, the correlation between these 


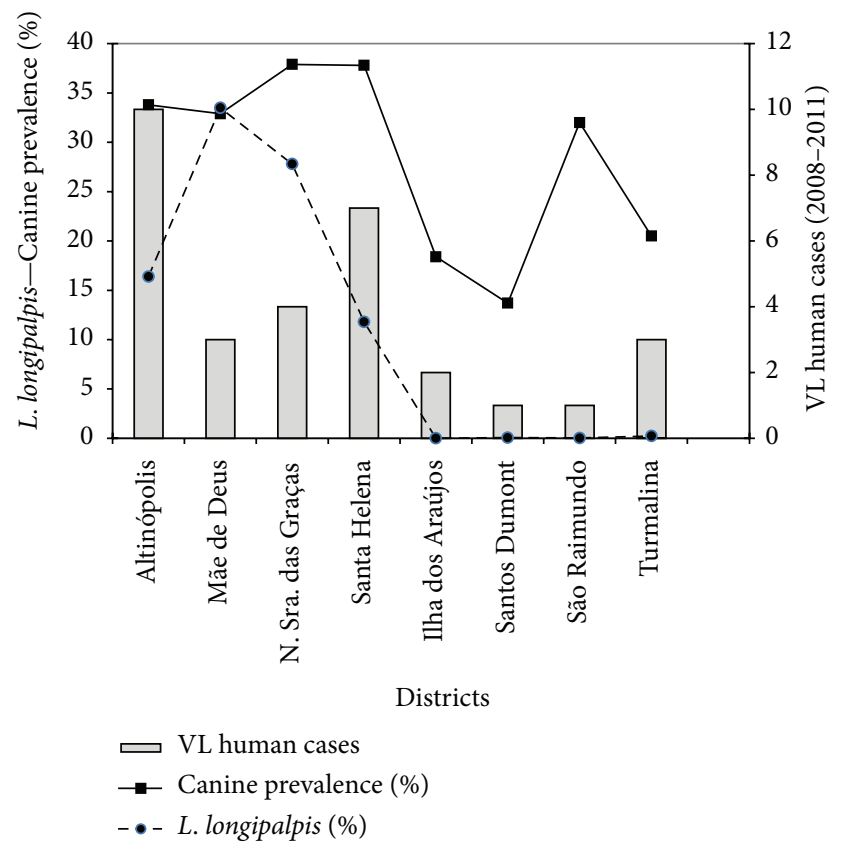

Figure 2: Distribution of Lutzomyia longipalpis population, prevalence of canine infection, and human cases VL per district of Governador Valadares, MG, Brazil.

two variables presented no statistical significance. However, if we analyze Figure 2, we notice that there is a tendency for an increase in canine prevalence in neighborhoods where the density of $L$. longipalpis is higher, such as Altinópolis, Nossa Senhora das Graças, Mãe de Deus, and Santa Helena.

Thus, these factors seem to be decisive for the occurrence of VL in the city of Governador Valadares, reinforcing the need for rigid controlling actions through the euthanasia of seropositive dogs, the use of residual insecticide, and environmental management in residences, as well as rigorous epidemiological surveillance.

\section{Acknowledgments}

The authors would like to thank Fundação de Amparo à Pesquisa do Estado de Minas Gerais (APQ-0098/10) for the financial support.

\section{References}

[1] C. M. F. Gontijo and M. N. Melo, "Leishmaniose visceral no Brasil: quadro atual, desafios e perspectivas," Revista Brasileira de Epidemiologia, vol. 7, no. 3, pp. 338-349, 2004.

[2] L. M. Deane and M. P. Deane, "Visceral leishmaniasis in Brazil: geographical distribution and trnsmission," Revista do Instituto de Medicina Tropical de São Paulo, vol. 4, pp. 198-212, 1962.

[3] R. J. Quinnell, O. Courtenay, L. Garcez, and C. Dye, “The epidemiology of canine leishmaniasis: transmission rates estimated from a cohort study in Amazonian Brazil," Parasitology, vol. 115, no. 2, pp. 143-156, 1997.

[4] J. C. França-Silva, R. T. da Costa, A. M. Siqueira et al., "Epidemiology of canine visceral leishmaniosis in the endemic area of Montes Claros Municipality, Minas Gerais State, Brazil," Veterinary Parasitology, vol. 111, no. 2-3, pp. 161-173, 2003.

[5] Brasil, Manual de vigilância e controle da leishmaniose visceral, MS, Série A. Normas e Manuais Técnicos, Ministério da Saúde. Secretaria de Vigilância em Saúde. Departamento de Vigilância Epidemiológica, Brasília, Brazil, 2006.

[6] M. V. Coelho and A. R. Falcão, "Aspectos epidemiológicos do calazar em Minas Gerais," Jornal Brasileiro de Medicina, vol. 10, no. 1, pp. 259-262, 1966.

[7] IBGE, "Anuário Estatístico do Brasil-Instituto Brasileiro de Geografia e Estatística," 2010.

[8] A. Voller, W. H. Bidwell, and I. Arjona, The Enzyme Linked Immunossorbent Assay (ELISA): A Guide with Abstracts of Microplate Applications, Dynatec Europe, 1979.

[9] M. E. Camargo and C. Rebonato, "Cross-reactivity in fluorescence tests for Trypanosoma and Leishmania antibodies. A simple inhibition procedure to ensure specific results," American Journal of Tropical Medicine and Hygiene, vol. 18, no. 4, pp. 500505, 1969.

[10] F. Mancianti, M. Gramiccia, L. Gradoni, and S. Pieri, "Studies on canine leishmaniasis control. 1. Evolution of infection of different clinical forms of canine leishmaniasis following antimonial treatment," Transactions of the Royal Society of Tropical Medicine and Hygiene, vol. 82, no. 4, pp. 566-567, 1988.

[11] H. Pugedo, R. A. Barata, J. C. França-Silva et al., "HP: um modelo aprimorado de armadilha luminosa de sucção para a captura de pequenos insetos," Revista da Sociedade Brasileira de Medicina Tropical, vol. 38, no. 2, pp. 70-72, 2005.

[12] D. G. Young and M. A. Duncan, "Guide to the identification and geographic distribution of Lutzomyia sand flies in Mexico, the West Indies, Central and South America (Diptera: Psychodidae)," Memoirs of the American Entomological Institute, vol. 54, no. 1, pp. 1-881, 1994.

[13] C. H. N. Costa, H. F. Pereira, and M. V. Araújo, "Visceral leishmaniasis epidemic in the State of the Piauí, Brazil (19801986)," Revista de Saúde Pública, vol. 24, no. 5, pp. 361-372, 1990.

[14] M. D. S. B. Nascimento, J. M. L. Costa, B. I. P. Fiori et al., "Aspectos epidemiológicos determinantes na manutenção da leishmaniose visceral no Estado do Maranhão, Brasil," Revista da Sociedade Brasileira de Medicina Tropical, vol. 29, no. 3, pp. 233-240, 1996.

[15] E. S. Silva, C. M. F. Gontijo, R. S. Pacheco, V. O. P. Fiuza, and R. P. Brazil, "Visceral leishmaniasis in the Metropolitan Region of Belo Horizonte, State of Minas Gerais, Brazil," Memorias do Instituto Oswaldo Cruz, vol. 96, no. 3, pp. 285-291, 2001.

[16] R. A. Barata, J. C. F. D. Silva, R. T. D. Costa et al., "Phlebotomine sand flies in Porteirinha, an area of American visceral leishmaniasis transmission in the State of Minas Gerais, Brazil," Memorias do Instituto Oswaldo Cruz, vol. 99, no. 5, pp. 481-487, 2004.

[17] E. M. Michalsky, J. C. França-Silva, R. T. Costa et al., "Leishmaniose Visceral: estudo de flebotomíneos e infecção canina em Montes Claros, Minas Gerais, Brasil," Revista da Sociedade Brasileira de Medicina Tropical, vol. 38, no. 2, pp. 147-152, 2005.

[18] R. Badaro, T. C. Jones, R. Lorenco et al., "A prospective study of visceral leishmaniasis in an endemic area of Brazil," The Journal of Infectious Diseases, vol. 154, no. 4, pp. 639-649, 1986.

[19] M. C. A. Marzochi, K. B. F. Marzochi, and R. W. Carvalho, "Visceral leishmaniasis in Rio de Janeiro," Parasitology Today, vol. 10, no. 1, pp. 37-40, 1994. 
[20] J. M. L. Costa, G. M. C. Viana, A. C. R. Saldanha et al., "Leishmaniose visceral no Estado do Maranhão, Brasil. Evolução de uma epidemia," Cadernos de Saúde Pública, vol. 11, no. 2, pp. 321-324, 1995.

[21] M. J. A. Queiroz, J. G. B. Alves, B. Jailson et al., "Leishmaniose visceral: características clínico-epidemiológicas em crianças de área endêmica," Jornal de Pediatria, vol. 80, no. 2, pp. 141-146, 2004.

[22] I. A. Sherlock and S. P. Almeida, "Notas sobre leishmaniose canina no Estado da Bahia," Revista Brasileira de Malariologia e Doenças Tropicais, vol. 22, no. 2, pp. 231-242, 1970.

[23] L. B. Iversson, M. E. Camargo, A. Villanova et al., "Inquérito sorológico para pesquisa de leishmaniose visceral em população canina-urbana do município de São Paulo-Brasil (1979-1982)," Revista do Instituto de Medicina Tropical de São Paulo, vol. 25, no. 6, pp. 310-317, 1983.

[24] S. G. Coutinho, M. P. Nunes, M. C. Marzochi, and N. Tramontano, "A survey for American cutaneous and visceral leishmaniasis among 1,342 dogs from areas in Rio de Janeiro (Brazil) where the human diseases occur," Memorias do Instituto Oswaldo Cruz, vol. 80, no. 1, pp. 17-22, 1985.

[25] T. G. Evans, I. A. B. Vasconcelos, J. W. Lima et al., "Canine visceral leishmaniasis in northeast Brazil: assessment of serodiagnostic methods," American Journal of Tropical Medicine and Hygiene, vol. 42, no. 2, pp. 118-123, 1990.

[26] M. P. Nunes, J. M. Jackson, R. W. Carvalho, N. J. Furtado, and S. G. Coutinho, "Serological survey for canine cutaneous and visceral leishmaniasis in areas at risk for transmission in Rio de Janeiro where prophylactic measures had been adopted," Memorias do Instituto Oswaldo Cruz, vol. 86, no. 4, pp. 411-417, 1991.

[27] L. C. C. Malaquias, R. do Carmo Romualdo, J. B. do Anjos Jr., R. C. Giunchetti, R. Corrêa-Oliveira, and A. B. Reis, "Serological screening confirms the re-emergence of canine leishmaniosis in urban and rural areas in Governador Valadares, Vale do Rio Doce, Minas Gerais, Brazil," Parasitology Research, vol. 100, no. 2, pp. 233-239, 2007.

[28] J. B. F. Vieira and G. E. Coelho, "Leishmaniose visceral ou calazar: aspectos epidemiológicos e de controle," Revista da Sociedade Brasileira de Medicina Tropical, vol. 31, supplement 2, pp. 85-92, 1998.

[29] L. C. P. de Oliveira, R. R. de Araújo, C. R. Alves, E. MoutaConfort, J. A. López, and F. W. de Mendonça-Lima, "Seroprevalence and risk factors for canine visceral leishmaniasis in the endemic area of Dias D'Ávila, State of Bahia, Brazil," Revista da Sociedade Brasileira de Medicina Tropical, vol. 43, no. 4, pp. 400404, 2010

[30] É. M. Michalsky, M. F. Rocha, A. C. V. M. da Rocha Lima et al., "Infectivity of seropositive dogs, showing different clinical forms of leishmaniasis, to Lutzomyia longipalpis phlebotomine sand flies," Veterinary Parasitology, vol. 147, no. 1-2, pp. 67-76, 2007.

[31] M. C. A. Marzochi, P. C. Sabroza, L. M. Toledo et al., "Leishmaniose Visceral na cidade do Rio de Janeiro-Brasil," Cadernos de Saúde Pública, vol. 1, no. 1, pp. 5-17, 1985.

[32] M. D. F. Madeira, A. D. O. Schubach, T. M. P. Schubach, C. A. Leal, and M. C. D. A. Marzochi, "Identification of Leishmania (Leishmania) chagasi isolated from healthy skin of symptomatic and asymptomatic dogs seropositive for leishmaniasis in the municipality of Rio de Janeiro, Brazil," The Brazilian Journal of Infectious Diseases, vol. 8, no. 6, pp. 440-444, 2004.
[33] E. D. Moreira Jr., V. M. M. de Souza, M. Sreenivasan, N. L. Lopes, R. B. Barreto, and L. P. de Carvalho, "Peridomestic risk factors for canine leishmaniasis in urban dwellings: new findings from a prospective study in Brazil," The American Journal of Tropical Medicine and Hygiene, vol. 69, no. 4, pp. 393-397, 2003.

[34] F. S. Julião, B. M. P. S. Souza, D. S. Freitas et al., "Investigação de áreas de risco como metodologia complementar ao controle da leishmaniose visceral canina," Pesquisa Veterinária Brasileira, vol. 27, no. 8, pp. 319-324, 2007.

[35] E. M. Michalsky, J. C. França-Silva, R. A. Barata et al., "Phlebotominae distribution in Janaúba, an area of transmission for visceral leishmaniasis in Brazil," Memórias do Instituto Oswaldo Cruz, vol. 104, no. 1, pp. 56-61, 2009.

[36] E. S. Dias, S. Regina-Silva, J. C. França-Silva et al., "Ecoepidemiology of visceral leishmaniasis in the urban area of Paracatu, state of Minas Gerais, Brazil," Veterinary Parasitology, vol. 176, no. 2-3, pp. 101-111, 2011.

[37] A. G. de Oliveira, E. A. B. Galati, O. de Oliveira et al., "Abundance of Lutzomyia longipalpis (Diptera: Psychodidae: Phlebotominae) and urban transmission of visceral leishmaniasis in Campo Grande, state of Mato Grosso do Sul, Brazil," Memorias do Instituto Oswaldo Cruz, vol. 101, no. 8, pp. 869-874, 2006.

[38] N. A. Missawa and E. S. Dias, "Phlebotomine sand flies (Diptera: Psychodidae) in the municipality of Várzea Grande: an area of transmission of visceral leishmaniasis in the state of Mato Grosso, Brazil," Memorias do Instituto Oswaldo Cruz, vol. 102, no. 8, pp. 913-918, 2007.

[39] R. A. Barata, G. F. Paz, M. C. Bastos et al., "Phlebotomine sandflies (Diptera: Psychodidae) in Governador Valadares, a transmission area for American tegumentary leishmaniasis in State of Minas Gerais, Brazil," Revista da Sociedade Brasileira de Medicina Tropical, vol. 44, no. 2, pp. 136-139, 2011.

[40] C. Margonari, C. R. Freitas, R. C. Ribeiro et al., "Epidemiology of visceral leishmaniasis through spatial analysis, in Belo Horizonte municipality, state of Minas Gerais, Brazil," Memorias do Instituto Oswaldo Cruz, vol. 101, no. 1, pp. 31-38, 2006.

[41] R. Lainson and B. F. Rangel, "Lutzomyia longipalpis and the eco-epidemiology of American visceral leishmaniasis, with particular reference to Brazil-a review," Memorias do Instituto Oswaldo Cruz, vol. 100, no. 8, pp. 811-827, 2005. 

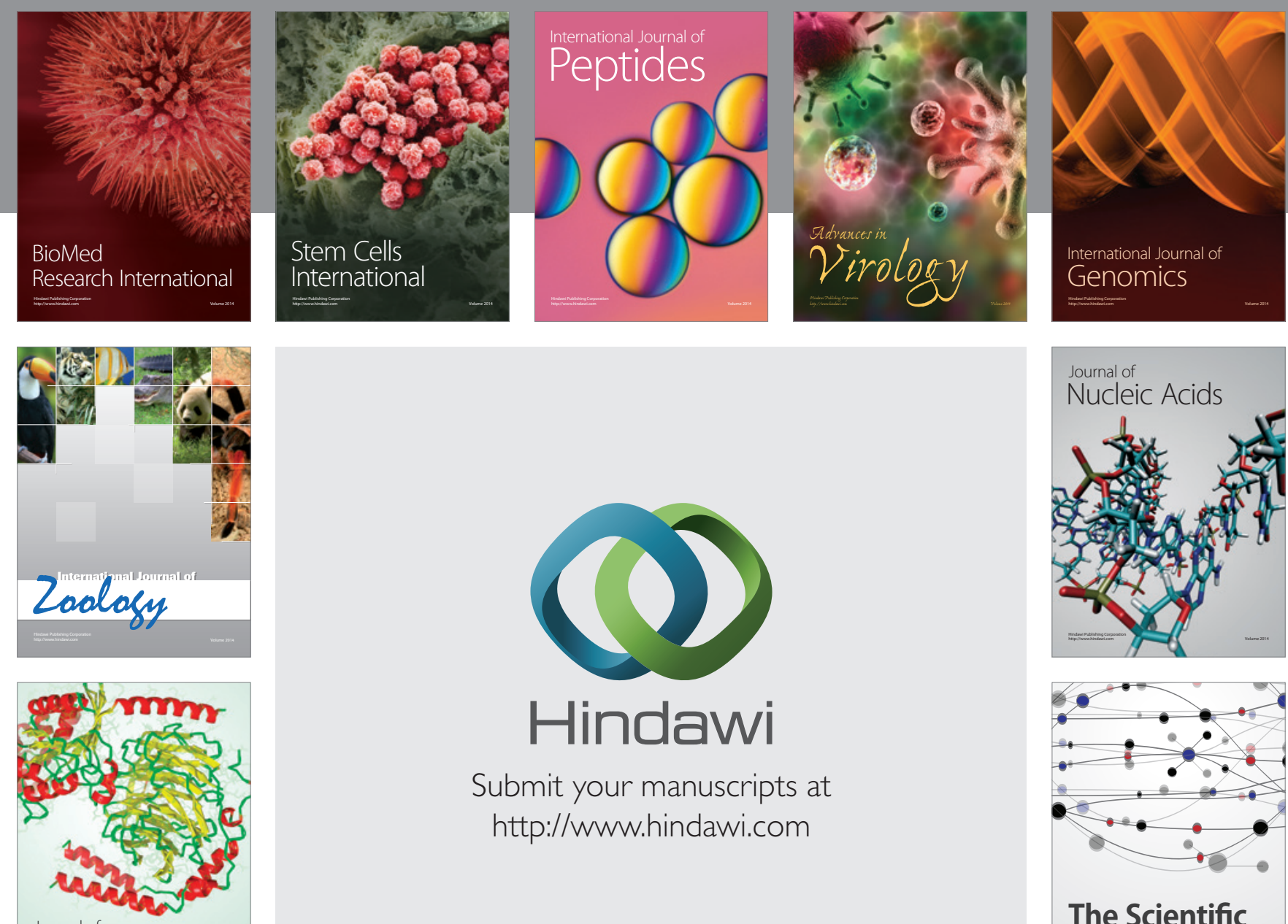

Submit your manuscripts at

http://www.hindawi.com

Journal of
Signal Transduction
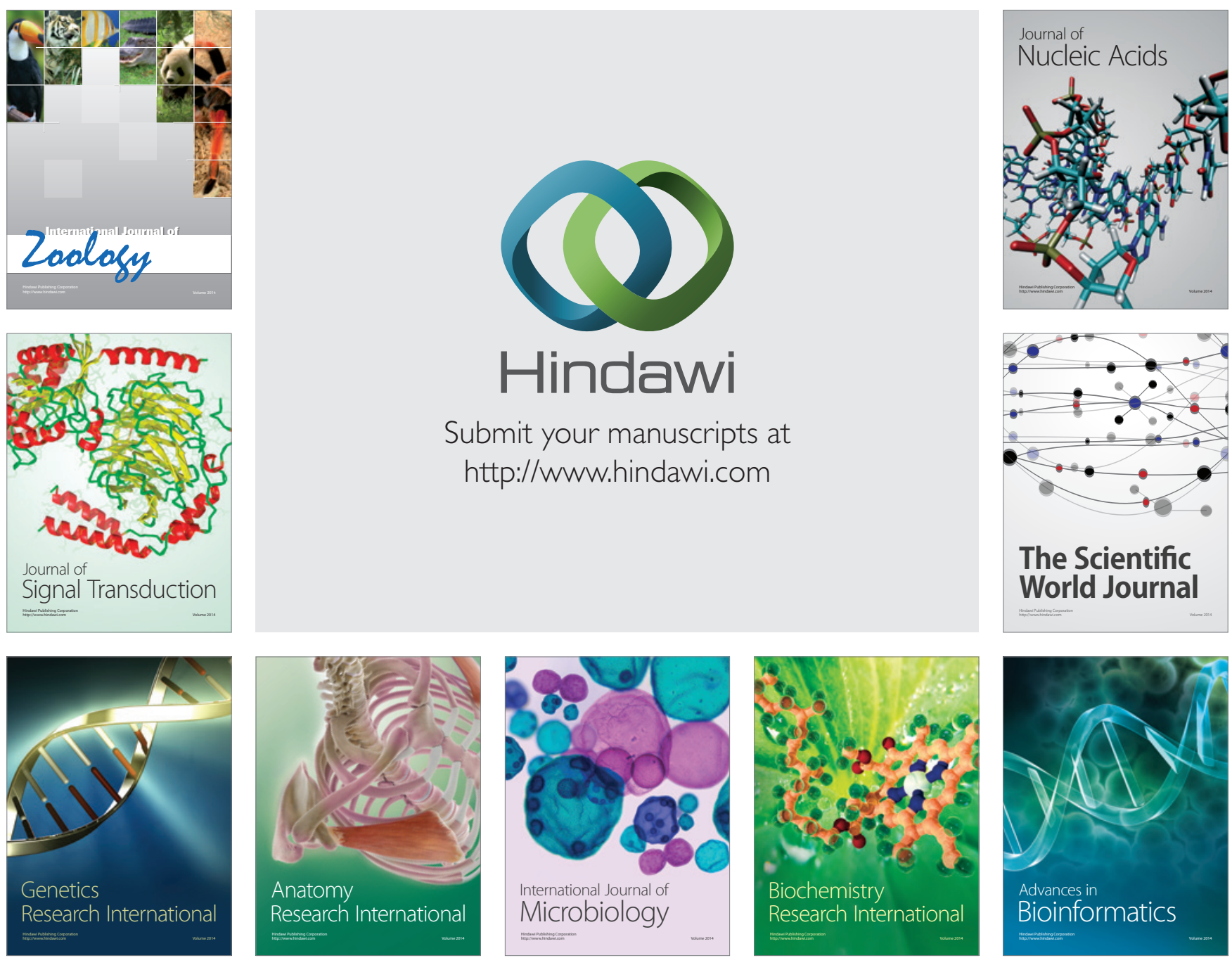

The Scientific World Journal
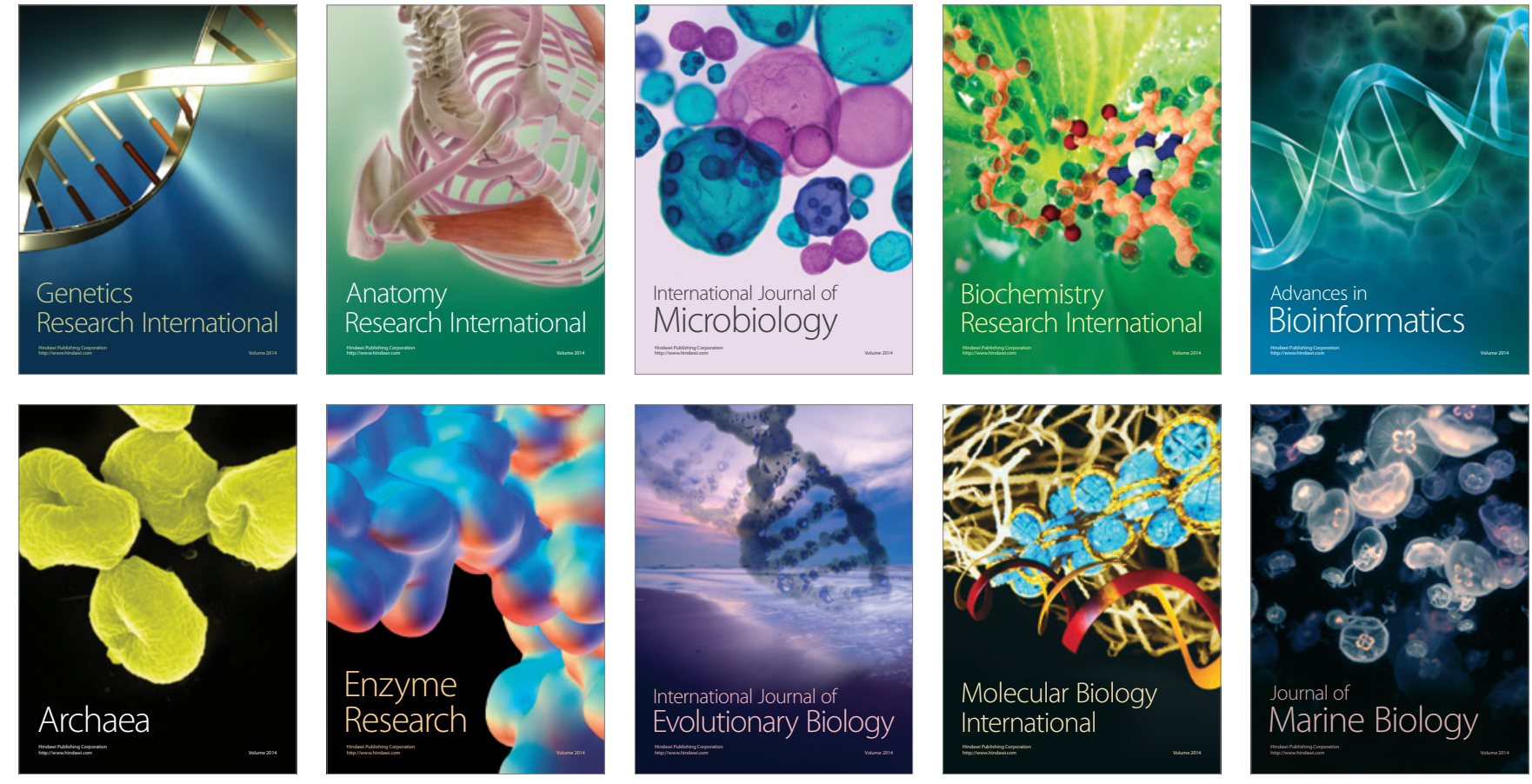